\title{
$\mathrm{UNLV} \mid \underset{\text { LIBRARIES }}{\mathrm{UNIVRSTT}}$
}

Library Faculty Publications

Library Faculty/Staff Scholarship \& Research

2004

\section{Bibliotherapy for Hospital Patients}

\author{
P. S. McMillen \\ University of Nevada, Las Vegas, psmcmillen.phd@gmail.com \\ D. Pehrsson \\ University of Nevada, Las Vegas, dale.pehrsson@unlv.edu
}

Follow this and additional works at: https://digitalscholarship.unlv.edu/lib_articles

Part of the Library and Information Science Commons, and the Mental and Social Health Commons

\section{Repository Citation}

McMillen, P. S., Pehrsson, D. (2004). Bibliotherapy for Hospital Patients. Journal of Hospital Librarianship, 4(1), 73-81.

https://digitalscholarship.unlv.edu/lib_articles/34

This Article is protected by copyright and/or related rights. It has been brought to you by Digital Scholarship@UNLV with permission from the rights-holder(s). You are free to use this Article in any way that is permitted by the copyright and related rights legislation that applies to your use. For other uses you need to obtain permission from the rights-holder(s) directly, unless additional rights are indicated by a Creative Commons license in the record and/ or on the work itself.

This Article has been accepted for inclusion in Library Faculty Publications by an authorized administrator of Digital Scholarship@UNLV. For more information, please contact digitalscholarship@unlv.edu. 


\section{SPECIALTY OF THE HOUSE}

\section{Bibliotherapy for Hospital Patients}

\section{INTRODUCTION}

The purpose of this paper is to provide a brief overview of bibliotherapy in relation to hospital patients. It includes a brief history as well as discussion of practitioners, patients and problems, methodology and effectiveness. It also offers recommendations for those who provide bibliotherapy within the hospital context. The focus is on the use of bibliotherapy by professionals other than mental health practitioners. Coverage includes common literary genres that can be used for bibliotherapy addressing patients' affective issues. For more information on literature used for patient education or consumer health information, see Bandy (1).

Defining bibliotherapy is challenging. Coined by Samuel Crothers in 1916, the term bibliotherapy is a combination of the Greek words for therapy and books (2). Indeed, the Greeks were well aware of the therapeutic power of books, inscribing over the door of the ancient library at Thebes the phrase "Healing place of the soul." Caroline Shrodes suggested bibliotherapy was the "process of dynamic interaction between the personality of the reader and literature under the guidance of a trained helper" (3). Laura Cohen provides a strikingly simple definition of it as the "therapeutic use of literature" (4). Others have attempted to subdivide the practice and the concept. It is useful to distinguish between clinical bibliotherapy, which is implemented by trained helping professionals dealing with significant emotional or behavioral problems, and developmental bibliotherapy which may be used by teachers and other lay helpers to facilitate normal development and self-actualization with an essentially healthy population (5-7). Another categorization found in the literature is between reading bibliotherapy, i.e., someone suggesting potentially beneficial reading to another without any further discussion or processing, and 
interactive bibliotherapy where a suggested reading serves as the catalyst for discussion and/or further therapeutic interactions (8).

\section{HISTORY}

In the early 1800's, reading became one of the most commonly used therapeutic interventions, second only to physical exercise. In the mid-nineteenth century, several major medical hospitals established patients' libraries whose primary goal was to provide reading matter to distract patients from their problems and give them a positive focus. The first records of hiring full-time trained librarians to oversee patient collections appeared in 1904 (9). The American Library Association (ALA) spearheaded the focus on services to institutionalized patients. Library standards were created that were endorsed by the American Hospital Association and the American College of Surgeons (10).

In both Britain and the United States, the First World War was a major impetus for establishment and/or expansion of patients' libraries in hospitals where librarians and volunteers used reading to help soldiers recover from physical as well as mental trauma. The War Service effort in America, run by the ALA, boasted of library service to more than 3,981 military service points (9). From 1920-1950, Sadie Peterson Delaney developed bibliotherapeutic services so effectively within the Veterans Administration Hospital system that she was asked to represent hospital librarians at a conference in Rome (11).

\section{PRACTITIONERS}

One of the ongoing debates has been over who should most appropriately be the helper/facilitator $(6,12)$. Physicians and librarians were the pioneers in bibliotherapy. The qualifications of physicians seem never to have been in question but debate has raged around whether or not librarians were sufficiently qualified. From the 1920's to the 1950's, there were 
efforts to enhance the training of librarians so that they would have a sufficient background to become the practitioners of record $(9,13,14)$. Programs were created at numerous library schools that ranged in length from intensive summer courses to a five-year program at The University of Minnesota's School of Medicine (9). The impetus for training in this type of librarianship has diminished, however (15).

Bibliotherapy is practiced by a variety of professions. Forrest's review of the bibliotherapy literature from 1993-1997 found that the authors fell into 4 main groups: psychologists (57\%), librarians (20\%), nurses (11\%), and social workers (10\%) (16). An interesting finding of the Matthews and Lonsdale study in Great Britain was that the primary implementers of bibliotherapy with children in hospitals were the hospital play specialists (17). Many have been wise enough to recognize that a collaborative venture between librarians and primary care providers would provide the best effort on behalf of patients $(6,12,14,16-18)$.

\section{PATIENTS AND PROBLEMS}

Currently, literature provided to adult patients is more often intended to educate them than to address their emotional needs (13). Yet it seems reasonable to conclude that people still experience many of the same fears, confusion, embarrassments, sense of lost control and increased vulnerability that they did in years past. Exceptions to this lack of attention to adults' emotional needs are described by Starker, who looked at VA medical outpatients and at patients in a cardiology practice, and by Cohen who used bibliotherapy for patients coping with a number of types of diseases $(4,19-22)$. Marrs' analysis provides an extensive bibliography of bibliotherapy studies, most of which used self-help or other informational literature (23).

Children, who were virtually never written about in the early decades of evolving bibliotherapy practice, are increasingly seen to be in need of emotional support. For children, 
bibliotherapy is used for diversion, entertainment, stress reduction, reassurance, and comfort (17, 24). Forrest's review of the recent bibliotherapy literature found $32 \%$ of the articles related to treatment of children or adolescents (16). Although most of these dealt with situational stressors (e.g., divorce, adoption), some studies also dealt with physical problems such as coping with disabilities.

\section{THERAPEUTIC MECHANISMS AND IMPLEMENTATION}

Most of those who use fictional literature still draw on the original psychodynamically oriented models of how bibliotherapy works. Readers are encouraged to identify with significant characters in the story (universalization), to experience emotional catharsis as the story characters express themselves (abreaction), and then to gain some insight into themselves and their situations (integration). When self-help or non-fiction literature is used, the therapeutic model is more often a cognitive behavioral one.

Laura Cohen attempted to understand the therapeutic mechanisms from the reader's perspective (8). She used a well-functioning, non-clinical adult population who believed that reading had helped them through difficult situations in their lives. The participants selected their own reading materials that ranged from poetry and fiction to motivational and self-help literature. Identification with the characters and/or situations in the selected literature was acknowledged by virtually all readers as the key to experiencing positive effects, regardless of the literary genre. While generalizations from this study are limited due to the selective nature of her population, the findings certainly seem to corroborate years of subjective reports that find bibliotherapy with patients to be "diversional, educational, and therapeutic" (25). Cohen likens the bibliotherapy process to the four-step nursing process model $(4,19)$. When applied effectively, each intervention employs assessment, planning, intervention and evaluation 
components. Cohen reports that reading was beneficial to many even when further contact with a therapist/helper was minimal or non-existent (8). This is consistent with reports of early bibliotherapy practice in hospitals where sometimes patients just took the books away and read them on their own. Although Marrs' analysis did not specifically include studies of medical patients, he also found that some problems were responsive to bibliotherapy regardless of the amount of therapist contact (23).

Those who work with children are more insistent regarding the necessity of direct facilitator involvement in the bibliotherapy process (15). No two individuals will react in the same fashion to a given piece of literature and careful monitoring of reactions is especially recommended with children. At the same time, offering children a choice of materials and letting them set the pace is emphasized $(7,15,17,26)$. Children and adolescents can be expected to go through similar stages as adults, usually with varying degrees of assistance from a facilitator. With younger children, this may mean aiding them to recognize similarities between their situation and the story characters' situation. Successful problem solving interventions may be learned as they apply story characters' behaviors and reactions to themselves. With adolescents, less intensive assistance is usually needed. Even with adults, however, it is appropriate to help patients identify with characters and situations in the reading since that recognition is considered by some to be a key step in the bibliotherapeutic process $(8,19,27)$.

Developmental or physical concerns may dictate that children or adults need to be read to; many individuals who are normally capable of reading on their own may not be able to do so effectively in a hospital setting due to medications, physical discomfort, interruptions and such. Narrative and stories are powerful no matter what one's age. Additionally, providing materials in alternate formats such as audio or Braille is a consideration with all age groups. Children's 
materials (e.g., picture books) may be appropriate for any age when reading or language abilities are limited or when physical, emotional or behavioral issues limit attention span. Work with all ages can involve creative adjuncts to the story telling or reading, such as use of puppets, drawing, writing, music, singing or even acting. Some options for working with adolescents are giving them opportunities to create alternative scenarios or endings, to write a letter from one character to another, or to create a diary for a character with whom they identify. Verbal sharing and role-playing are potential alternatives to writing. Many writers provide suggested ways to interact with literature that are widely adaptable to various patients, problems and settings (24, 28-29).

Cautionary advice on using bibliotherapy abounds in the literature. Predominantly, practitioners insist that recommenders be well acquainted with the content of their materials. They need to be sensitive to cultural, ethnic and religious messages. Monroe points out that although the area may be more sensitive and open to abuse than other areas, "the ethical considerations involved in bibliotherapy are no different from those in any area of reader services" (30). Particularly in the health care field, writers continue to emphasize the importance of ensuring that any descriptions of medical procedures or personnel are accurate and up to date (e.g., 24). In recent years, the emphasis has shifted to a more positive focus on finding stories with characters and situations similar enough to the reader's own to facilitate some level of identification. Some differences between the characters and the reader/listener can be used therapeutically to increase empathy and understanding for those from different backgrounds, or to provide needed distance from painful emotions. There has been a notable increase in children's literature in recent years with a wealth of choices on almost any issue or problem that 
might be faced. Manworren \& Woodring offer excellent guidelines on selection and use of literature with pediatric patients (24).

\section{EFFECTIVENESS}

It has been as hard to document the isolated effects of bibliotherapy as it has been with other types of dynamic therapies. Subjective reports of positive benefits in emotional well-being abound in the professional literature, but the only strong consistent experimental findings come from those studies which use non-fiction/self-help literature as the intervention. In summarizing their review of the recent research literature on bibliotherapy, Pardeck and Pardeck report that several studies found positive outcomes using self-help books with adults to address health related problems, including improved attitudes towards problems and treatment, and lowered stress levels (28). Marrs conducted a large and statistically rigorous meta-analysis which reached the overall conclusion that bibliotherapy had a positive therapeutic effect (23). Unfortunately there were too few studies using fictional literature and affective approaches which met the study's criteria to draw any meaningful conclusions, and the analysis was limited to research studies primarily in the psychological and educational literature.

\section{RECOMMENDATIONS}

Below are some basic recommendations for bibliotherapy. The nursing process model of assessment, planning, intervention and evaluation offers a useful framework $(4,19)$. In the assessment phase, emotional, cognitive, physical and developmental factors must be considered. Practitioners would do well to consult family and staff caregivers who can potentially provide information about the interest and capacity of patients for independent reading, as well as their mental and emotional status. Further, practitioners can evaluate these issues with the patients themselves through conversations about their medical conditions, by reading sample passages 
together and through discussion of recreational reading interests. The relative grasp which patients exhibit of the medical issues involved in their personal situations can guide practitioners in choosing whether the reading material should be selected for diversion, reassurance, or informational purposes.

Therapeutic goals for bibliotherapy should be clarified and possibly include a formal treatment plan made in consultation with other members of the healthcare team. Consideration must be given to the most appropriate materials to address the goals in the patient's situation, an area where librarians can provide expert assistance and consultation. It is important to determine not only what issues might best be addressed by the subject matter, but also the level of reading difficulty, accuracy of any information about medical procedures, and any particular values or viewpoints represented. Thoroughly previewing the material will help avoid unpleasant surprises and will increase the practitioner's comfort level. The assessment process should guide planning for the selection, amount, reading level, type of literature, and potentially the mode of delivery.

One key to effective implementation is to practice ahead of time. There are many ways to utilize materials and each patient is unique. Some patients gain most from reading materials in silence; many enjoy being read to or reading together. If the setting is appropriate, one may consider oral reading in a group followed by discussion or writing a response to the reading. Whatever manner practitioners choose to present the bibliotherapy, facilitating identification between the patient and the characters'situation in the reading is essential to the patient deriving the maximum benefit. Practitioners may want to discuss emotions elicited by the reading activity, being particularly sensitive to any negative emotions that might impede the treatment 
and trying to offer perspective without cutting off legitimate feelings. One of the real benefits of reading can be seeing how others have dealt with problems or survived difficult situations.

Evaluation can be as informal as making notes after a discussion of the reading or it might involve a more formalized case consultation with the entire healthcare team. Patient's reactions, feedback and progress should guide further interventions. Whatever the strategy for evaluation, the focus will be on the patient's emotional well-being, which is positively correlated with compliance and recovery (27). Evaluation can also promote the development of resources for the patient.

\section{SUMMARY}

Although some studies have looked at the use of bibliotherapy as a stand-alone intervention, most advocates promote bibliotherapy as an adjunct to other therapies and would agree with Riordan and Wilson who offer, "The real question is not whether bibliotherapy is or is not effective as a separate therapy but rather how and when it should be used as part of a treatment program" $(15,28,31)$. The literature continues to provide support for the benefits of this low-cost, low-tech, yet high-impact approach.

Living your life is a long and dodgy business... and stories and books help. Some help you with the living itself. Some help you just take a break. The best do both at the same time (32).

Paula McMillen, Ph.D., Social Science Librarian \& Asst. Prof., Oregon State Univ. Dale E. Pehrsson, Ph.D., Asst. Prof. Counselor Education, Oregon State Univ.

\section{REFERENCES}

1. Bandy M. Health information for patients and consumers. In: Holst R, Phillips SA, editors. The Medical Library Association guide to managing health care libraries. NewYork: Neal-Schuman Publishers, Inc; 2000. p. 325-50. 
2. Crothers SM. A literary clinic. Atl Mon 1916 Sept;118(3):291-301.

3. Shrodes C. Bibliotherapy: a theoretical and clinical-experimental study [dissertation]. Berkeley (CA): University of California; 1950.

4. Cohen LJ. Discover the healing power of books. Am J Nurs 1993 Oct;93(10):70, 72-4, 76-80.

5. Afolayan JA. Documentary perspective of bibliotherapy in education. Read Horiz 1992;33(2):137-48.

6. Doll B, Doll C. Bibliotherapy with young people: librarians and mental health professionals working together. Englewood (CO): Libraries Unlimited; 1997.

7. Kramer PA, Smith GG. Easing the pain of divorce through children's literature. Early Child Educ J 1998;26(2):89-94.

8. Cohen LJ. The experience of therapeutic reading. West J Nurs Res 1994;16(4):426-37.

9. Panella NM. The patients' library movement: an overview of early efforts in the United States to establish organized libraries for hospital patients. Bull Med Libr Assoc 1996;84(1):52-62.

10. ALA Joint Committee on Standards for Hospital Libraries. Hospital libraries: objectives and standards. Rev. ed. Chicago: The Association; 1968.

11. Gubert BK. Sadie Peterson Delaney: pioneer bibliotherapist. Am Libr 1993;24(2):124-5, 127, 129-30.

12. Hannigan MC. Counseling and bibliotherapy for the general reader. In: Monroe ME, editor. Reading guidance and bibliotherapy in public, hospital and institution libraries: a selection of papers presented at a series of adult services institutes, 1965-1968. Madison (WI): Library School of the University of Wisconsin; 1971. p. 45-50. 
13. Holst R. Hospital libraries in perspective. Bull Med Libr Assoc 1991;79(1):1-9.

14. Tews RM. The role of the librarian on the interdisciplinary team. In: Monroe ME, editor. Reading guidance and bibliotherapy in public, hospital and institution libraries: a selection of papers presented at a series of adult services institutes, 1965-1968. Madison (WI): Library School of the University of Wisconsin; 1971. p. 57-62.

15. Schlenther E. Using reading therapy with children. Health Libr Rev 1999;16(1):2937.

16. Forrest MES. Recent developments in reading therapy: a review of the literature. Health Libr Rev 1998;15(3):157-64.

17. Matthews DA, Lonsdale R. Children in hospital: II. Reading therapy and children in hospital. Health Libr Rev 1992;9(1):14-26.

18. Monroe ME. Services in hospital and institution libraries. In: Casey GM, editor. Libraries in the therapeutic society. Chicago: ALA Association of Hospital and Institution Libraries; 1971. p. 11-3.

19. Cohen LJ. Here's something I want you to read. RN 1992 Oct;55(10):56-9.

20. Starker S. Characteristics of self-help book readers among VA medical outpatients. Med Psychother 1992;5:89-93.

21. Starker S. Self-help books: ubiquitous agents of health care. Med Psychother 1990;3:187-94.

22. Starker S. Self-care materials in the practice of cardiology: an explorative study among American cardiologists. Patient Educ Couns 1994;24(1):91-4. 
23. Marrs RW. A meta-analysis of bibliotherapy studies. Am J Community Psychol 1995;23(6):843-70.

24. Manworren RCB, Woodring B. Evaluating children's literature as a source for patient education. Pediatr Nurs 1998;24(6):548-53.

25. Forrest MES. Fifty years of patients' libraries. Health Libr Rev 1998;15(4):267-78.

26. Aronoff M. Abel's Island: a case study in bibliotherapy. Br J Ther Rehabil 1998;5(3):157-64.

27. Hodges B, Craven J, Littlefield C. Bibliotherapy for psychosocial distress in lung transplant patients and their families. Psychosomatics 1995;36(4):360-8.

28. Pardeck JT, Pardeck JA. Children in foster care and adoption: a guide to bibliotherapy. Westport (CT): Greenwood Press; 1998.

29. Heiney SP. The healing power of story. Oncol Nurs Forum 1995;22(6):899-904.

30. Monroe ME. Reader services and bibliotherapy. In: Monroe ME, editor. Reading guidance and bibliotherapy in public, hospital and institution libraries: a selection of papers presented at a series of adult services institutes, 1965-1968. Madison (WI): Library School of the University of Wisconsin; 1971 p. 40-4.

31. Riordan RJ, Wilson LS. Bibliotherapy: does it work? J Couns Dev 1989;67(9):506-8. 32. Fine A. Goggle-eyes. London: Puffin; 1990. p. 139. 